\title{
Inter-institutional collaboration - challenge and important way in improving the management of local government units in Albania.
}

\author{
Dorina Leka ( Klosi) \\ $\mathrm{PhD}$ Candidate at European University of Tirana \\ klosidori@yahoo.it
}

\section{DOI:10.5901/mjss.2014.v5n19p296}

\section{Abstract}

\begin{abstract}
The organization of local government in Albania is characterized by a large number of local government units, division of territory in very small units and three government levels that often can not divide clearly the competences between them. Local government faces challenges every day that are becoming ever more complex due to increased public xpectations in terms of offered quality of services, employment opportunities, possibilities to solve faster and efficiently the emergent needs and opportunity to absorb as many funds as possible, especially funds of IPA which provide the opportunity to implement larger and long-term projects, etc..In the paper will be given information on concrete examples of inter-institutional collaboration among local government units, legal spaces and the limits of the law in this regard, legal instruments used for these collaborations, funding mechanisms and incentives, the fact that they have been successful, identification of the barriers and opportunities for the community benefit. It will also provide ideas for a new collaboration possibility such as the management of human resources. So far, inter-institutional collaboration in Albania has been focused only on the area of public services, but for the first time, the New Law of the Civilian Employee creates the possibility that this collaboration can be extended also in the field of human resources. Until February 2014, month in which the new law began its effects of civil servants in Albania, the local government does not fully benefit from the legal regulations in the field of civil service. With the entry into force of this law, now the three levels of local government are included in the field of civil service and will be able to manage human resources according to principles laid down in the law and take advantage of the civil service system as an unique system.
\end{abstract}

Key words: quality of services, new collaboration possibility, management of human resources, unique system, legal instruments, barriers, opportunities.

\section{Introduction}

The vision of the organization of local government in Albania is in accordance with the Constitution, the principles of the European Charter of Local Autonomy and the goals of the country for development in the context of European integration.

The vision of the organization for local government in Albania takes into consideration the fact that decentralization and local authorities represent the basic principles of consolidated democracies.

Under the Constitution, the local governance in Albania is organized in two levels of districts and communes/municipalities, which are local public decentralized and autonomous authorities responsible for delivering and distributing the public goods and services.

Relations between them are characterized by their cooperation, complementarities and a clear division of tasks within a coherent legal framework.

Albania's territorial division is based on Law no. 8652/2000 "On the organization and functioning of local government" and Law no. 8653/2000 "On the administrative and territorial division", which brought the creation of 373 local units of the first level (65 urban municipalities and 308 rural communes) and 12 local units of second level or districts.

A municipality is an administrative-territorial unity and a community of residents mainly in urban areas and in special cases it includes even rural areas. The territorial space, the name of the municipality and its city center are defined by law.

The commune represents also an administrative-territorial unity and a community of residents mainly in rural areas and in special cases in urban areas. The territorial space, the name and the center of the commune are defined by law. 
The districts are the second level unit of local government. The district represents an administrative-territorial unity, consisting of several communes and municipalities that have geographic, traditional, economic, social relation and common interests with each other. (Table 1, data of 2009).1

Given the legal framework communes and municipalities are the closest administration to the recipient and have clearly defined their duties and responsibilities.

The district is an upper level of local government. The purpose of their establishment was to create an instrument which would enable and assist the central government in drafting the new regional politics and programs for the development of disadvantaged areas in order to eliminate inequality between disadvantaged areas and the average of Albania. In this way the actors were given opportunities to local, regional and national level to contribute and collaborate to maximize the development potential in these areas.

\section{Problems of territorial division in Albania}

\section{A. Administrative Territorial Structure}

Albania has a fragmented system of local government with a very large number of local government units that have no fiscal or human capacities to provide public services at a reasonable level. According to the Civil Registry Data in Albania are 46 municipalities in less than 2,000 inhabitants and 107 units (103 communes and 4 municipalities with 2000-5000 inhabitants), thus constituting 415 local government units with less than 5,000 inhabitants2. (Table 2, the number of municipalities and communes by population).

Currently with the territorial division of local government in Albania, the right of local government units to run efficiently and the right of citizens to participate in decision making fail to be exercised fully and to give their results in improving the life of citizens.

\section{B. Fiscal Decentralization}

Fiscal decentralization is not yet well developed in Albania with all the performed progress. The decentralization reform has brought an increase of local autonomy in terms of incurring expenditure, but more rapidly in terms of local autonomy in terms of revenue. Currently, local governments now manage over 80 local taxes and fees, which grow year by year. From year to year are added functions that the central government has passed to local government units. Today these units perform about 31 functions. However inadequate legal regulations, such as restrictions imposed in the law on local borrowing or absence of a specific law on local finances has made that in this direction there are enough problems, which have affected also the manner of exercising the functions and quality of public services offered to the community.

In general, fiscal decentralization is associated with lower efficiency of use of financial resources and high cost of administrative expenses. Number of local units that have very weak financial situation is high, especially of those units with small populations and few natural resources or in terms of business development. So about 220 communes spend more than $40 \%$ of the budget for administrative costs. About 110 communes provide income from fees and local taxes 0 $10 \%$ of their budget and from these 70 communes have 0 the level of tax collection. 3

According to the report: fiscal decentralization indicators for Eastern Europe 2006-2011:4

Albania ranks last in terms of local revenue as percentage of GDP.

Albania ranks third from the bottom in terms of local income/capita in 737 Euro leaving behind Kosovo with 587 Euro and Moldova with 518 Euro.

Albania together with Kosovo and Bulgaria are the only countries that do not use sharing of personal income tax.

\footnotetext{
${ }^{1}$ Data taken from the document Inter-sectoral Strategy of Decentralization and Local Governance, prepared by the Ministry of Interior

2 Data taken from the document Project of Planning and Local Governance in Albania, prepared by the United States Agency for International Development

3 Data taken from Inter-sectoral Strategy of Decentralization and Local Governance, Ministry of Interior

${ }^{4}$ Report of Associations Network of Local Authorities of South East Europe, second edition, November 2012
} 
Albania ranks second from the bottom in terms of property tax collection as percentage towards GDP in 2011 with only $0.18 \%$ leaving behind only Croatia by $0.13 \%$.

Albania ranks last in relation to local government investment as percentage towards GDP to $0.9 \%$.

Albania ranks penultimate after Moldova in terms of per capita outstanding debt of local government units with 23 Euro per capita.

\section{Table 3: Application of taxes from local government units}

\section{Table 4: Application of taxes from local governments units}

With the current division of the territory and form of decentralization, the efficiency and economies of scale are not achieved, then it is touched the principle of subsidiary. We can mention the case of the final treatment of solid waste, the form of the transfer of responsibilities on water-supply and sanitation, urban planning when should be taken into consideration implications in neighboring local unit, inter-urban public transport, local administrative capacity not of the level with scale of the problem that must be faced, etc.. Due to lack of efficiency and legislation on standards, are offered non-qualitative services and lack of access that undermines the goal of decentralization, which is to provide qualitative services for citizens. One of the major problems that has presented this territorial division is the fact that also the funds allocated to these local government units are fragmented and therefore by their use is not achieved the proper economy and efficiency.

While the challenges they should face become more complex:

Citizens expectations about the qualities and types of public services increase, as they are becoming more and more part of a globalized world.

Local businesses seek increasingly more financial support and infrastructure, but local governments have difficulty attracting funding in the function of investments performance.

Most of young people abandon the rural areas unable to find a work, adding the number of unemployed in urban areas.

Many municipalities and communes are small and are unable to provide financial funding or expertise to carry out a good governance.

For example how could a local government body with 5000 inhabitants can manage good the domestic waste, when a modern processing plant requires a minimal population of 7000 residents?

When from the data of the Ministry of Interior issued by the National Registry of Civil Status 178 communes and 6 municipalities have under 7,000 residents. 1

This problem can be solved through cooperation of local governments of different levels, through inter-local cooperation.

\section{What is the inter-local cooperation?}

An instrument used by two or more local authorities working together within their legal powers to:

Perform administrative functions

Promote local development

Provide public/social services

There can be forms and various reasons for the application of this instrument, but in all cases there are some common features. Inter-local collaboration occurs when two or more municipalities or communes agree to work together to achieve a mutual benefit in connection with the services that they should provide to the community.

Inter-local collaboration does not refer to:

National/regional associations representing the interests of local authorities in negotiations with government

Change of jurisdiction/administrative borders through amalgamation

Cross-border cooperation between municipalities of neighbor countries

${ }^{1} \mathrm{Mol}$, General Directorate of Civil Status, January 01st, 2014 
This instrument has:

its technical dimension, because it requires planning and management skills

cultural dimension because it requires a leadership with a positive and cooperative approach

above all it requires legal support, a flexible legal framework and financial incentives for certain objectives

\section{Legislation enabling the inter-local collaboration}

In Albania, the main legislation that enables the inter-local collaboration is:

Constitution of Republic of Albania, which in Article 109/4 provides: "The bodies of local governments have the right to form unions and joint institutions with each other to represent their interests."

The European Charter of Local Self-Government of the Council of Europe, adopted in May 1998, which in Article 10/1 states: "Local authorities have the right to cooperate while exercising their powers, and within the legal framework can form partnership with other local authorities in order to carry out the tasks of common interest".

Law no. 8652 "On the organization and functioning of local government bodies" which in some of its articles recognizes the right of local councils that can establish institutional agreements for co-management of various functions of local government. The law requires that these agreements:

Describe the purpose and functions to be exercised

To provide the manner whereby it shall be completed the goal

To determine the extent and duration of the delegation of powers

To determine the manner and measure of the division of revenues and other benefits from the activity.

Law no. 10296, dated August 07th, 2010 "On the financial management and control", which in Article 3/2 states that the field of law enforcement includes: "Corporations, non-profit organizations and joint authorities, which are owned, controlled, financed or financially guaranteed by a unit of general government (general government = central government and local government)".

There are also mechanisms of financing by state budget of the central government for cooperation agreements such as joint stock companies subsidies of water-supply and sanitation for polluted waters.

Another mechanism of central government that encourages and supports inter-local cooperation is also the Regional Development Fund, which is considered as the only instrument that somewhat addresses the problems of regional development. Regional Development Fund (RDF) is a financial instrument aimed to distribute the central funds for investments to local governments on a competitive basis and aims to harmonize national and local budgetary policies. Regarding this it is worthy to point out some issues as:

RDF funds are allocated on the basis of criteria defined by normative act1, but allocation based on competitive grants makes it more project-oriented than an instrument that addresses the regional development. A large part of the local units have no skilled technical capacity to implement programs in order to benefit financial instruments from the fund.

Competitive nature creates the problem of "closed circuit of low capacities" (which has happened in Bulgaria) which means development opportunities only for a limited group of actors, usually those most developed. Thus the weak risks to weaken even more, because to him is not provided specific support2.

There is very little knowledge about RDF and mode of application, and a large part of the local units apply to the old format of competitive grants. This conclusion has emerged from a survey carried out by an UNDP project.

And finally all the institutions that will be involved in managing this fund, need to strengthen existing capacities and building new capacities.

The main areas and reasons for inter-local cooperation.

${ }^{1}$ DCM no. 135, dated February 03 rd, 2010 "On defining the criteria for allocation of funds for development of regions"

2 Marinov, 2010 
The main areas where an inter-local cooperation could be extended affect practically the vital services of a community and as such can be listed:

Health, social assistance, education, environmental management, waste management, water distribution and sanitation, economic development, culture, urban planning, roads, public transport, fire services, tax collection, public procurement and human resources.

The cooperation of local government units in all areas listed above leads to:

Harmonization, unification, development of common policies for all areas, unifying priorities and objectives in broader geographic areas and for a greater number of people.

Enhancing the quality of services, their availability and the possibility of using an advanced technology.

Opportunities to attract major funds for the realization of projects.

Efficiency and effectiveness in service delivery. Reduction of fiscal evasion and increasing specialization of human resources.

Increase the purchasing power of the community.

Increase the standard of human resources.

From a research conducted by the Swiss Agency for Development and Cooperation in partnership with the Ministry of the Interior and Local Government Associations, in which participated $83 \%$ of communes and municipalities and $78 \%$ of district, results that all participants confirm willingness to cooperate with other units of local government and rank 7 functions as the main interest for cooperation.

Table 5: Ranking the fields of cooperation for which there is an interest1

\section{Also from the research showed that:}

To the question whether they have knowledge on the inter-local cooperation, $83 \%$ of communes and municipalities and $78 \%$ of districts responded that they have general knowledge and only $15 \%$ of communes and municipalities and $22 \%$ of districts responded that they have no knowledge.

To the question of who are the channels of information, $59 \%$ of communes and municipalities and $89 \%$ of districts responded that national associations are the main channels of information and these are the government and its agencies.

To the question whether the government encourages the inter-local cooperation, $72 \%$ of communes and municipalities and $78 \%$ of districts have responded positively.

Many local governments consider inadequate legal environment to assist local governments in creating and using different instruments of inter-local cooperation and require that the national legislation and local councils should define the specific rules of cooperation.

Inter-local cooperation in Albania so far in all cases has its partner the first level of local government, communes and municipalities. Districts so far have seen their role as encouraging and not only as a facilitator or participant in collaboration and there is only one case when in cooperation has participated a Sub-Prefecture.

So far $37 \%$ of communes and municipalities report formalized cooperation with other local units in the form of:

Agreements, used for delegation of powers to the district or other units of the first level. Typical are the cases of urban or construction inspectorates.

Establishment of legal entities, public enterprises, joint stock company or associations with the participation of private business. Typical are the associations of water supply and cleaning.

As reported by local units in all cases collaboration is realized with financial support of donators and mainly foreign ones.

1 Initial report to the Inter-Municipal Cooperation, March 2012 


\section{Positive examples of inter-local cooperation}

Despite all the difficulties in Albania, currently there are some successful examples of inter-local cooperation. Let mention some of them:

Region of Korca, Form of cooperation: Management or urban waste

Number of local units participating in the collaboration 28 communes, with a total population of beneficiaries.

Legal form: Joint Stock Company

Funding: KFW, the contributions of units, revenue from cleaning fees.

\section{Region of Berat, Form of cooperation: water supply and sanitation}

The number of member units 2 enterprises and 6 local units with a total population of beneficiaries.

Legal form: Joint Stock Company

Funding: KFW, the contributions of local units

District of Shkodra, Form of cooperation: cleaning service

The number of member units: 5 local units, 1 municipality and 4 municipalities, with a total population of beneficiaries

Legal form: Association

Funding: COSPE, contributions of local government units, revenue from cleaning fees

\section{District of Shkodra, Form of cooperation: Depositing of urban waste}

The number of participating units: 11 local units, of which 3 municipalities and 8 communes with a total population of beneficiaries.

Legal form: Association

Funding: COSPE, contributions of local government units from cleaning fee.1

From what it is reported form the national associations of local governments, except of these most successful cases and in typical areas where exists an inter-local cooperation until now, there has been only one case of cooperation in the field of administrative services with the aim of cutting costs and there is no single case of cooperation in the field of human resources management.

The reasons that have hindered the inter-local cooperation to be further developed:

mentalities and political divisions

problems in financing projects

lack of inventory of properties by local authority and the barriers showed by the central government in carrying out this process

Lack of human resources to enable the drafting of agreements, practices and their further management.

\section{Human Resources, a new area of inter-local cooperation}

Human resources are the most vulnerable part when it comes to local government units in Albania.

1 Information received from 
Large population movements since 1990, with the change of political system in Albania continuing during 20 years later, made that in remote areas qualified human resources has moved and especially young people who try to be employed in urban areas because of higher payment, better living conditions and better job.

What we all recognize today in Albania is the fact that in local units there are less qualified human resources, who are able to respond to the challenges and demands of the time.

The loss of population in a large part of communes has also brought the departure of educated human resources on what makes difficult the use and implementation of reforms in order to increase the quality of life in communities.

In about 80 communes, especially those with less than 5,000 inhabitants, $70 \%$ of administration is without university education.

This phenomenon and this inability in terms of qualified human resources has led to the fact that since 1999 when in Albania came into force the first law "On the Status of Civil Servants", communes were excluded from this law due to the inability of the selection of candidates to be adapted to the requirements of the job position.

In all cases of inter-local collaborations, expertise or advising is made by international organizations and local experts employed by these organizations.

If local governments would seek to apply the forms of cooperation in terms of human resources, the supporting legislation in this regard almost doesn't exists.

There is only one law in which it is clearly expressed the fact that each local unit may borrow sources of other units, but also this in contractual form and approved in advance by the central government. Law "On Auditing in Public Sector" .

Since February 2014 is entered into force a new law "On Civil Servant", number 152/2013, which has extended its scope to all local government units on both levels. The basic principle of this law is conducting recruitments in group or massive recruitments and on national level.

In manner that this principle can be realized and implemented realistically the spirit of the law, the government strongly advises local governments to extend their cooperation also in this regard.

We would have:

\section{Respecting the legal law in the employment field}

Opportunities for local governments for capacity expansion and selection of the best cases

Cuts of administrative costs

The new law sees the civil service system as a unique, within which we have mobility plans of the employees for their needs or institutions, to improve capacities etc.. In this context, local units within a broader region, could benefit from cooperation providing to the citizens the opportunity to expand the employment market.

In manner that all above can be accomplished, it is required a great collaboration between local governments and government agencies to enable recognition of the law and its proper meaning.

In this context, the government is also assisted by the Swiss Cooperation Office in Albania and Council of Europe, who in recent months have organized trainings with units of human resource management of local units and government experts.

By all participants in the training is evident the desire to implement the law and to cooperate in this field being aware of the importance of this major component as a qualified employee.

Two key objectives on which stands the European Cohesion Policy are: efficiency and equity. While ISRD emphasizes mainly the development of the legal framework and institutional capacity and does not answer to the question whether in a country like Albania we will support efficiency or equality? The answer to this question will certainly affect the territorial division, efficiency and role of the Counties, creating regions, their form and size.According to ISRD, the approach to regional development is more internally focused than integrated in the European concept of Regional Development (RD).But, funds that Albania will benefit from IPA III and will be managed centrally, will initially focus on EU priorities and national priorities through major infrastructure investments in transport, environment and regional competition. 
IPA III budget will finance projects with the highest values (values that will be more than 10 million euro). This means that at the beginning Albania will not be able to address its regional problems through these funds. At first interest is to treat disparities between our country as a single region of the EU and other countries of the Community.

Therefore, what is required is a convergence of internal RD with IPA III and a gradual adaptation of RDF as the only current mean for this convergence. In terms of limited time, money and human resources, this alternative is an opportunity to be more efficient with used resources and without risking losing strategic orientation.

To be successfully carried out, it is required:

Limited changes in the institutional structure to allow more focus on human capacity building who need to gain knowledge and experience.

Maintain management and programming responsibilities at central level and local units specialization in project management.

A clear definition of responsibilities in the implementation of investments between the central and local authorities so that possible financing, management and programming collisions can be avoided.

It would also require some changes that can be made to RDF:

Review the basis upon which it relies to shift from the current focus towards projects in terms of development programs. This would allow a better connection of RDF with budget legislation.

The best connection of RDF that is managed centrally with development strategies of special Counties.

Special support for areas in advantage absence.

In conclusion, anyway it depends on the progress that Albania will make with efforts to establish an institutional framework and human capacities, which should be proficient in management, programming and implementation of EU financial support, with the ultimate goal of ensuring efficient use of these funds.

\section{Bibliography}

Legislation on local government online www.qpz.gov.al Inter-sectoral Strategy for Regional Development online

Co-Plan, Institute for Habitat Development, Impact of Policy-making, Policy Briefs, December 2008

OECD, 2009, How regions are developed, www.oecd.org/publications/policybriefs

McClements c, 2010 Cross - cutting strategy for regional development, Albania, Review

Marinov V, D. Malhassian 2002, measures and evaluations of regional disparities and their policy implications: the case of Bulgaria

Barca F 2009 An agenda for a reformed cohesion policy, www.eurada.org/site/files/regional1\%20development/Barca report.pdf

\section{European Commission 2004 Progress Report on Albania}

Strategy of Decentralization and Local Governance, prepared by the Ministry of Interior

Project of Planning and Local Governance in Albania, prepared by the United States Agency for International Development

Report of Associations Network of Local Authorities of South East Europe, second edition, November 2012

DCM no. 135, dated February 03rd, 2010 "On defining the criteria for allocation of funds for development of regions Initial report to the Inter-Municipal Cooperation, March 2012

Law number 8788, date 7.5.2001" On non-profitable organization" 


\section{Tables}

Tab. 3 Application of taxes from local government units

\begin{tabular}{|c|c|c|c|c|c|c|}
\hline Fees & Municipalities & $\%$ & Communes & $\%$ & Total & $\%$ \\
\hline Cleaning fee & 63 & 97 & 166 & 54 & 229 & 74 \\
\hline $\begin{array}{l}\text { Transport } \\
\text { License }\end{array}$ & 47 & 72 & 167 & 54 & 214 & 69 \\
\hline $\begin{array}{l}\text { Income from } \\
\text { Tenders }\end{array}$ & 43 & 66 & 139 & 45 & 182 & 59 \\
\hline $\begin{array}{l}\text { Business } \\
\text { Registration }\end{array}$ & 44 & 68 & 114 & 37 & 158 & 51 \\
\hline $\begin{array}{l}\text { Administrative } \\
\text { Acts }\end{array}$ & 28 & 43 & 99 & 32 & 127 & 41 \\
\hline $\begin{array}{l}\text { Income from } \\
\text { Parking }\end{array}$ & 44 & 68 & 29 & 9 & 73 & 24 \\
\hline Hunting Fee & 16 & 25 & 40 & 13 & 56 & 18 \\
\hline \multicolumn{7}{|l|}{ Other Income } \\
\hline $\begin{array}{l}\text { From } \\
\text { Agricultural } \\
\text { Land }\end{array}$ & 2 & 3 & 4 & 1 & 6 & 2 \\
\hline Lands & 16 & 25 & 24 & 8 & 40 & 13 \\
\hline Buildings & 8 & 12 & 4 & 1 & 12 & 4 \\
\hline $\begin{array}{l}\text { Specific } \\
\text { Objects }\end{array}$ & 2 & 3 & 2 & 1 & 4 & 1 \\
\hline $\begin{array}{l}\text { Rent from } \\
\text { Buildings }\end{array}$ & 39 & 60 & 43 & 14 & 82 & 27 \\
\hline $\begin{array}{l}\text { Rent from } \\
\text { Agricultural } \\
\text { Land }\end{array}$ & 6 & 9 & 15 & 5 & 21 & 7 \\
\hline Rent of Lands & 25 & 38 & 58 & 19 & 83 & 27 \\
\hline
\end{tabular}

Tab. 4 Application of taxes from local governments units

\begin{tabular}{|l|l|l|l|l|l|l|}
\hline \multirow{2}{*}{ Denomination } & \multicolumn{2}{l|}{ Municipalities } & \multicolumn{2}{l|}{ Communes } & \multicolumn{2}{l|}{ Total } \\
\cline { 2 - 8 } & No. & $\%$ & No. & $\%$ & No. & $\%$ \\
\hline Tax on Building & 62 & 95 & 235 & 76 & 297 & 96 \\
\hline Tax on Agricultural Land & 32 & 49 & 231 & 75 & 263 & 85 \\
\hline Tax on New ConstructionS & 42 & 65 & 91 & 30 & 133 & 43 \\
\hline Table Fee & 57 & 88 & 162 & 53 & 219 & 71 \\
\hline
\end{tabular}




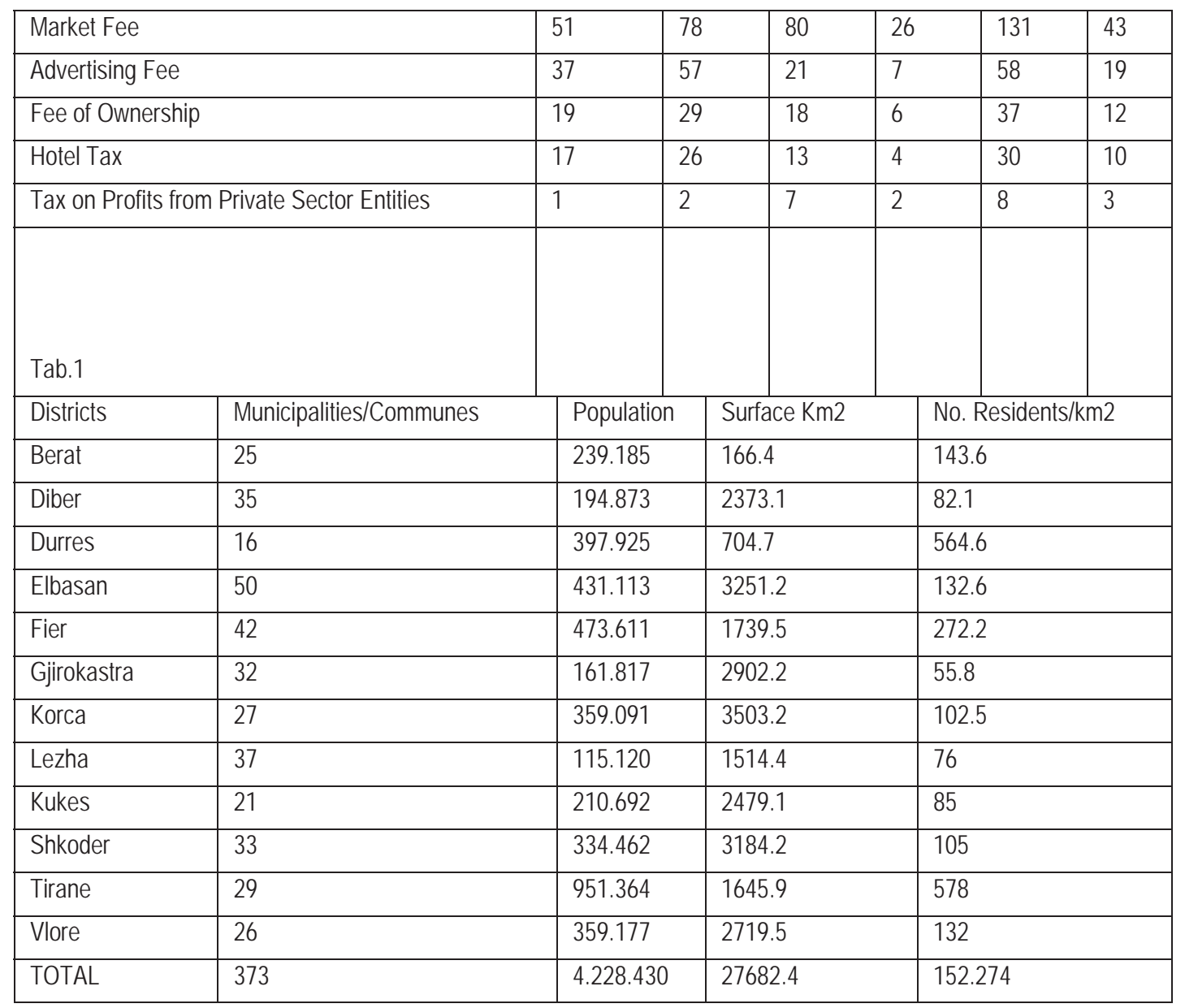

Tab. 2 The number of municipalities and communes by population.

\begin{tabular}{|c|c|c|c|c|c|c|c|c|c|}
\hline \multirow{2}{*}{$\begin{array}{l}\text { No. Local } \\
\text { Government } \\
\text { Units/population }\end{array}$} & \multicolumn{8}{|c|}{ Number of population } & \multirow[t]{2}{*}{ Total } \\
\hline & $<2000$ & $\begin{array}{l}2000> \\
5000\end{array}$ & $\begin{array}{l}5000> \\
10000\end{array}$ & $\begin{array}{l}10000> \\
15000\end{array}$ & $\begin{array}{l}15000> \\
30000\end{array}$ & $\begin{array}{l}30000> \\
100000\end{array}$ & $\begin{array}{l}100000> \\
200000\end{array}$ & $\begin{array}{l}> \\
2000000\end{array}$ & \\
\hline Municipalities & 0 & 4 & 17 & 18 & 10 & 11 & 3 & 2 & 65 \\
\hline Communes & 46 & 103 & 102 & 41 & 15 & 1 & 0 & 0 & 308 \\
\hline Total & 46 & 107 & 119 & 59 & 25 & 12 & 3 & 2 & 373 \\
\hline
\end{tabular}

Tab.5. Ranking the fields of cooperation for which there is an interest

\begin{tabular}{|l|l|l|}
\hline Fields of interest & Commune/Municipality in \% & Districts in \% \\
\hline Local economic development & 80 & 100 \\
\hline
\end{tabular}




\begin{tabular}{|l|l|l|}
\hline Environmental protection & 76 & 100 \\
\hline Tourism promotion & 67 & 100 \\
\hline Urban planning, territory management, building permits & 59 & 100 \\
\hline Protection of cultural-historical buildings & 57 & 89 \\
\hline Protection of forests, pastures, natural resources & 54 & 89 \\
\hline Response to emergencies & 54 & 89 \\
\hline
\end{tabular}

Tab.6 Albania has serious problems in deepening inequality

\begin{tabular}{|l|l|l|l|l|l|l|l|l|}
\hline No. & County & Population & $\begin{array}{l}\text { Poverty } \\
\text { level/ } \\
\text { national } \\
\text { average } \\
\text { in } \%\end{array}$ & $\begin{array}{l}\text { Unemployment } \\
\text { rate/ national } \\
\text { average in \% }\end{array}$ & $\begin{array}{l}\text { Local } \\
\text { future/ } \\
\text { national } \\
\text { average } \\
\text { in \% }\end{array}$ & $\begin{array}{l}\text { Access to } \\
\text { water } \\
\text { supply/ } \\
\text { national } \\
\text { average } \\
\text { in\% }\end{array}$ & $\begin{array}{l}\text { No. } \\
\text { medical } \\
\text { visits/ } \\
\text { national } \\
\text { average } \\
\text { in \% }\end{array}$ & $\begin{array}{l}\text { Completing } \\
\text { obligatory } \\
\text { education/ } \\
\text { national } \\
\text { average } \\
\text { in\% }\end{array}$ \\
\hline 1 & Berat & 181901 & 96 & 99 & 74.6 & 114 & 107 & 368 \\
\hline 2 & Diber & 166367 & 59 & 85 & 61.4 & 54 & 70 & 55 \\
\hline 3 & Durres & 280996 & 102 & 117 & 106 & 131 & 68 & 53 \\
\hline 4 & Elbasan & 380593 & 80 & 110 & 70 & 83 & 62 & 147 \\
\hline 5 & Fier & 380737 & 85 & 133 & 77 & 91 & 83 & 76 \\
\hline 6 & Gjirokaster & 80646 & 131 & 118 & 112 & 97 & 132 & 385 \\
\hline 7 & Korçe & 263586 & 94 & 126 & 78 & 97 & 127 & 202 \\
\hline 8 & Kukes & 102036 & 63 & 42 & 74 & 91 & 56 & 54 \\
\hline 9 & Lezhe & 159882 & 69 & 61 & 78 & 58 & 89 & 162 \\
\hline 10 & Shkoder & 250351 & 77 & 52 & 67 & 74 & 120 & 75 \\
\hline 11 & Tirana & 677871 & 108 & 168 & 160 & 123 & 140 & \\
\hline 12 & Vlora & 202295 & 139 & 89 & 139 & 132 & 92 & 506 \\
\hline & & 3127261 & & & & & & \\
\hline
\end{tabular}

